\title{
The Healthfulness of Food and Beverage Purchases after the Federal Food Package Revisions: The Case of Two New England States
}

\author{
Tatiana Andreyeva, $\mathbf{P h D}^{1}$ \\ Amanda S. Tripp, $\mathbf{P h D}^{2}$
}

\begin{abstract}
Affiliations: ${ }^{1}$ Department of Agricultural and Resource Economics, Rudd Center for Food Policy \& Obesity, University of Connecticut, Hartford, CT

${ }^{2}$ At the time this manuscript was completed, Dr. Tripp was a student at the Yale School of Public Health, Yale University, New Haven, CT. She is now at The Lewin Group, Falls Church, VA.

Address correspondence to: Tatiana Andreyeva, Rudd Center for Food Policy \& Obesity University of Connecticut, 1 Constitution Plaza, Hartford CT, 06103.

Phone: (860) 380-1014. Email: tatiana.andreyeva@uconn.edu
\end{abstract}

Word counts: Abstract: 250; Text: 3485; Table: 3, Appendix: 4.

Key words: WIC, food purchases, food spending, dietary quality, food policy, scanner data

Funding disclosure: This manuscript was supported by a grant from the Institute for Research on Poverty (IRP) RIDGE Center for the National Food and Nutrition Assistance Research program. The content is solely the responsibility of the authors and does not necessarily represent the official views of the IRP, RIDGE or USDA.

Acknowledgement: The authors express special thanks to the confidential grocery store chain for sharing their data. The authors appreciate helpful suggestions from the two reviewers. 


\begin{abstract}
Objective: In 2009, the Special Supplemental Nutrition Program for Women, Infants, and Children (WIC) implemented new food packages to improve dietary intake among WIC participants. This paper examines how the healthfulness of food purchases among low-income households changed following this reform.
\end{abstract}

Methods: Point-of-sale data for 2,137 WIC-participating and 1,303 comparison households were obtained from a regional supermarket chain. The healthfulness of purchased foods and beverages was determined per their saturated fat, sugar, and sodium content. A pre-post assessment (20092010) of the product basket healthfulness was completed using generalized estimating equation models. Data were analyzed in 2015.

Results: At baseline, healthy products accounted for most of the food volume purchased by WIC participants, but beverages were dominated by moderation (less healthy) items. With new subsidies for fruit, vegetables and whole grains, the WIC revisions increased the volume of healthy food purchases of WIC-participating households by $3.9 \%$ and reduced moderation foods by $1.8 \%$. The biggest improvements were reductions in moderation beverages (down by $24.7 \%$ in volume), driven by milk fat restrictions in the WIC food package revisions. The healthfulness of the product basket increased post-WIC revisions; mainly due to a reduction in the volume of moderation food and beverages purchased (down by $15.5 \%$ ) rather than growth in healthy 
products (up by $1.9 \%$ ). No similar improvements were seen in a comparison group of lowincome nonparticipants.

Conclusions: After the WIC revisions, the healthfulness of participant purchases improved, particularly for beverages. Efforts to encourage healthy eating by people receiving federal food assistance are paying off. 


\section{BACKGROUND}

For many American families, poor diet quality is a significant barrier to improving health and prolonging a disease-free lifespan. This is especially true for low-income families that have economic, time and access barriers to putting nutritious meals on the table. Poor diets in lowincome communities are the result of both compositional and environmental factors, ${ }^{1-3}$ including disparities in access to healthy food, ${ }^{4-5}$ higher prices, and poor product quality. ${ }^{1,6,7}$

Federal food assistance programs support one in four American households in achieving adequate nutrition. ${ }^{8}$ Economic incentives provided by these programs could be one strategy to improving the food environment and diet quality in low-income communities and reducing inequalities. The Special Supplemental Nutrition Program for Women, Infants, and Children (WIC) provides a set of nutrient-dense foods (via WIC food packages), nutrition education, and medical referrals to 8.0 million participants, ${ }^{9}$ including $51 \%$ of infants born in the U.S., $28 \%$ of children age five and under, $29 \%$ of pregnant women, and $30 \%$ of postpartum women. ${ }^{10}$ Because of its broad reach and targeted impact at a critical age of human growth and development, WIC has considerable potential for early intervention to establish healthier eating habits in lowincome populations.

The WIC food packages were initially revised in 2007 to increase participants' consumption of fruits, vegetables and whole grains while reducing saturated fat, cholesterol and sugar intake. Additional goals were to promote breastfeeding, provide WIC participants with a wider variety of food options and give states greater flexibility in administering the program. ${ }^{11,12}$ Designed as cost-neutral changes, the WIC revisions were implemented in all states by October 2009 and finalized in 2014. The changes included the addition of whole grain products, fruit and 
vegetable cash value vouchers, reductions in milk, cheese and juice allowances, restrictions on milk fat content, and incentives to encourage breastfeeding. The revisions provided a unique natural experiment to assess the ability of food assistance policy to improve diet quality in lowincome populations.

There is substantial interest in the impact of the WIC revisions on dietary and health outcomes in low-income populations. There is evidence that the WIC revisions have improved the availability and variety of healthy foods in underserved communities, ${ }^{13-18}$ including in nonWIC stores that were not subject to the WIC regulations requiring to stock healthier foods. ${ }^{13} \mathrm{~A}$ number of studies documented improvements in food choices aligned with the revisions: reduced participant purchases of juice, ${ }^{19}$ whole milk and cheese, ${ }^{20}$ and instead more fruit, vegetables ${ }^{21}$, low-fat milk ${ }^{20}$ and whole grain products ${ }^{22}$.

Importantly, the WIC food package revisions were associated with improved dietary intake of WIC participants. ${ }^{23}$ In a national sample, WIC-participating children were found to have a 3.7 point higher Healthy Eating Index (HEI) compared to eligible nonparticipants. ${ }^{24}$ Further evidence of similar improvements were reported in the WIC National Food and Nutrition Survey (NAFTAN), ${ }^{25}$ survey data from California ${ }^{26}$ and New York $^{27}$ and dietary assessments in Chicago. ${ }^{28}$ There was mixed evidence on breastfeeding initiation and intensity ${ }^{23}$, with only a small change in duration of breastfeeding ${ }^{29-30}$ or increases in local populations such as Los Angeles County. ${ }^{31}$ Finally, obesity rates among preschool-age children ${ }^{32-33}$ and low-income young children in particular ${ }^{34-35}$ started to decline recently. For example, obesity rates among all U.S. children aged 2-5yr declined from a peak of 13.9\% in 2003-2004 before the WIC revisions 
to $8.4 \%$ in $2011-2012$ and $9.4 \%$ in $2013-2014 .^{33}$ It remains to be seen how the WIC revisions affect diet quality and obesity among WIC participants in the long term.

This paper contributes to the WIC evaluation literature by examining the healthfulness of the total product basket purchased by WIC-participating households after implementation of the WIC food package revisions in Connecticut and Massachusetts.

\section{RESEARCH DESIGN}

Data: The study is based on point-of-sale data from a supermarket chain with more than 60 stores in New England, U.S. This chain has a loyalty card system, which allows customers to benefit from store promotions and price discounts. A unique feature of the data is information on the source of funds used to pay for each purchase, including: SNAP benefits, WIC benefits, cash assistance or non-SNAP electronic benefit transfers (EBT), and other funds (e.g., cash). A household's redemption of benefits indicates program participation at the time of each transaction, which we use to measure a household's WIC, SNAP and non-SNAP EBT participation status. We do not have purchases made without the use of loyalty cards, which is a small share of all transactions ( $<5 \%$, according to the supermarket). As using a loyalty card provides substantial price discounts on a variety of products, most customers, but especially more price-sensitive low-income households, have a strong incentive to use their card for all purchases. One loyalty card is assumed to represent one household, although in reality some families could have multiple cards or multiple households within the same extended family could share a single card. 
Sample: The sample is drawn from low-income households that used WIC benefits when shopping at the grocery chain in January 2009-December 2010. We do not have data for households that never used WIC benefits to pay for any of their purchases (e.g., high-income families not receiving assistance). Approximately half of the sampled WIC households also used SNAP benefits. Due to de-identified nature of the point-of-sale data, no socio-demographic information was available.

As the WIC package revisions went into effect in both states on October 1, 2009, we selected a panel of 2,137 households that shopped at the chain using WIC on a regular basis (at least quarterly) before and after the change: January-September 2009 (pre-revision) and JanuarySeptember 2010 (post-revision). The period of October-December 2009 was excluded to isolate the effects of the transition period when both the old and new WIC packages were in circulation. A comparison sample of 1,303 households was selected from former WIC households that were low-income due to a recent history of WIC participation, but were not expected to be affected by the WIC revisions as they were no longer participants. Specifically, households were selected into the comparison group if they used WIC benefits in the first quarter of 2009, but discontinued using WIC through the end of 2009 and all 2010 while still shopping regularly at the store.

We examined all purchases made by WIC-participating households during Jan-Sept 2009 and Jan-Set 2010 (N=199,085 transactions in the two states). For comparison households, we assessed all their purchases during Apr-Sept 2009 and Apr-Sept 2010, excluding the time period when they participated in WIC (Jan-Mar 2009) and a matching 3-month period in 2010 ( $\mathrm{N}=58,050$ transactions). Household (or loyalty card) level data were aggregated at the monthly level; if a household made multiple purchases per month, purchases were summed. 


\section{Product Identification and Categorization}

Each product sold at the chain has a unique Universal Product Code (UPC), which is linked to description of a product, department, category and sub-category in the store proprietary database. To retrieve nutrition information, product/container size and ingredients for all purchased UPCs, two syndicated databases were merged with the store UPC data: Gladson ${ }^{36}$ and Information Resources, Inc. (IRI). ${ }^{37}$ Gladson was first matched (60\% match by UPC), followed by IRI ( $83 \%$ match). Given its more recent records, IRI overrode Gladson if there was conflicting information. For UPCs that lacked information in the databases (e.g., store prepared foods, private label), online search was completed to look up individual UPCs.

The sample of WIC-participating and comparison households purchased a total of 29,204 unique food and beverage UPCs during the 18 months of our analysis. Non-food products were not included in this analysis. Each food and beverage UPC item was assigned to one of 12 categories and 44 sub-categories (Appendix 1) based on categorization in the USDA Food Intake Surveys: What We Eat in America, Food Categories 2001-2010 ${ }^{38}$ and Food Patterns Equivalents Database 2005-2006. ${ }^{39}$ For categories that included grains, we categorized products as $100 \%$ whole grain, some whole grain, refined grain (0\% whole grain), or no grain. We used the Food Patterns Equivalents Database methodology and a guide for the National School Lunch and Breakfast programs ${ }^{40}$ to identify whole grain products. Two coders reviewed and verified all UPC coding and product categorizations.

Product Healthfulness Classification: Each food and beverage was classified as either a Healthy, Neutral or Moderation (less healthy) product based on criteria in the USDA Economic Research Service study. ${ }^{41}$ The study classified primary food groups as Vegetables, Fruits, Dairy, 
Proteins, Grains and Mixed Dishes, and required minimal serving sizes to be considered meeting the recommended amount to provide nutrition. As our purchase data did not include consumption information, the recommended serving size was used to establish foods that would meet minimal thresholds. The ERS study classified consumption as healthy based on meeting the sodium, saturated fat and added sugar thresholds listed below. Consumption of foods above the threshold in any of the three areas was classified as moderation (unhealthy).

\begin{tabular}{|l|l|l|l|}
\hline Category & Sodium & Saturated Fat & Added Sugar \\
\hline $\begin{array}{l}\text { Vegetable, Fruit, Dairy and } \\
\text { Grains }\end{array}$ & $<480 \mathrm{mg}$ per serving & $<3 \mathrm{~g}$ per serving & $<4 \mathrm{~g}$ per serving \\
\hline Meat & $<480 \mathrm{mg}$ per serving & $\leq 4 \mathrm{~g}$ per serving & $<4 \mathrm{~g}$ per serving \\
\hline Mixed Dishes & $<600 \mathrm{mg}$ per serving & $<5 \mathrm{~g}$ per serving & $<5 \mathrm{~g}$ per serving \\
\hline
\end{tabular}

For vegetables, fruits, dairy, meat and grains, we used the same thresholds as the ERS study to categorize individual products. Because manufacturers only report total sugar, a number of assumptions were made regarding products containing naturally-occurring sugars, such as fruit, fruit juices and dairy. Specifically, all fruits and 100\% fruit juices with no added sugar were considered below the threshold and healthy. Juices with added sugar were considered above the sugar threshold. Milk and cheese products with no added sugar were classified below threshold for sugar, but flavored milk with added sugar was a moderation product. Yogurts were considered below the added sugar threshold if total sugar was below $20 \mathrm{~g}$ per serving. Checks to evaluate differences in sugar content among products with no added sugar and those with added sugar were completed to validate our assumptions.

Because the serving size of many condiments and oils does not meet minimal serving sizes to be considered nutritive, these products were categorized differently. Oils below saturated 
fat threshold (e.g., olive oil) were classified as neutral products and oils above thresholds as moderation. Snack foods with some whole grain or $100 \%$ whole grain and meeting the thresholds for sodium, saturated fat and added sugar were classified as healthy. Snack foods, which met all thresholds, but not whole grain, were classified as neutral. All infant formula and baby foods were classified as neutral. Unsweetened bottled water was classified as healthy while diet and low-calorie beverages, coffee and tea were neutral. Sugar-sweetened beverages were classified as moderation. Appendix 1 presents the healthfulness distribution of purchased foods and beverages, with over half of purchased items (52\%) categorized as moderation products.

\section{Data Analysis}

Dependent Variables: We calculated spending (measured in U.S. dollars) and the amount or volume purchased (measured in ounces) for healthy, neutral and moderation products and their totals before and after the WIC revisions. As beverages tend to be cheaper per ounce than solid food, we examined food separately from beverages.

Independent Variables: Household-level controls included measures of SNAP participation and cash assistance receipt, shopping frequency (number of transactions), month, and state indicators. Socio-demographic characteristics of the census tracts, linked to census-

level data from the 2006-2010 American Community Survey, ${ }^{42}$ where households shopped were added to account for differences in prices, product selection and marketing across stores located in different neighborhoods/towns. To some extent, these could capture lacking household-level socio-demographics. The weighted average of census-tract measures was calculated for households shopping in multiple stores based on frequency of store visits. 
Regression Modeling: As outcome variables (ounces purchased and spending) have a natural bound at zero and are positively skewed, we estimated generalized linear models (GLM) from the Poisson family with a logarithmic link function. ${ }^{43}$ To account for repeated observations within households, we used generalized estimating equations (GEE) with exchangeable working correlation and robust standard errors. ${ }^{44}$ GEE is an extension of GLM for longitudinal or clustered data. This model estimates the adjusted mean difference between the two time periods, controlling for covariates:

$E\left[Y_{i t} \mid X_{i}, X_{i t}\right]=\exp \left(\beta_{0}+\beta_{1} * R_{E V I S I O N}{ }_{i t}+\beta_{2} * \operatorname{SNAP}_{i t}+\beta_{3} * \mathrm{EBT}_{i t}+\beta_{4} * N_{T R A N S}{ }_{i t}+\beta_{5} * T_{i t}+\beta_{6} * S_{i t}\right)$

where REVISION ${ }_{\mathrm{it}}$ is an indicator for the time period ( 1 for post-revision and 0 for pre-revision); $\mathrm{SNAP}_{\mathrm{it}}$ is a household $i$ that used SNAP benefits at time $t, \mathrm{EBT}_{\mathrm{it}}$ is receipt of cash assistance by household $i$ at time $\mathrm{t}, \mathrm{NTRANS}_{\mathrm{it}}$ is the number of transactions at time $t, \mathrm{~T}_{\mathrm{it}}$ is a set of eight binary variables indicating the month of purchase, and $\mathrm{S}_{\mathrm{it}}$ is a vector of store area covariates.

All regressions were estimated separately for WIC-participating and comparison households. We limited the time period for WIC households to match the comparison group (Apr-Sept 2009 and Apr-Sept 2010) in a sensitivity analysis. Additional analyses included estimation of models for each food sub-category as well as interaction tests to understand if the WIC revisions had differential effects on certain WIC households. Specifically, we considered presence of an infant in the household (based on purchases of baby food and/or infant formula), SNAP participation, low-/high-income area of the store location, and state.

This study was exempt by the university IRB as from review due to secondary nature of de-identified data. 


\section{RESULTS}

Prior to the WIC revisions, foods and beverages purchased with WIC benefits accounted for $28 \%$ of product volume and $22 \%$ of expenditures among WIC-participating households (Table 1). In 2010, reduced allowances in the new WIC packages (especially milk and juice) contributed to the decline in the share of WIC-paid purchases: to $22 \%$ in volume and $19 \%$ in expenditures. Several products had a reduction in volume purchased: infant formula (down by 35\%), milk (26\%), 100\% juice (20\%), and eggs (30\%) (Appendix 2). At the same time, produce and whole grain purchases increased due to the new WIC allowances. Overall, expenditures and purchases by WIC-participating households declined after the WIC revisions (volume declined by $6.9 \%$ and expenditures by $7.7 \%$ ), driven entirely by a reduction in beverages. Comparison households reduced purchases of both food and beverages.

In 2009, beverages dominated WIC household purchases (Appendix 2), led by milk (17\% of all food and beverage volume), sugary beverages (16\%), and fruit juice (8\%). Comparison households bought substantially less milk and $100 \%$ juice (10\% and 4\% respectively), potentially due to loss of WIC benefits providing these products. The most important contributor to their purchases were sugary beverages ( $20 \%$ of volume) and mixed dishes (12\% of expenditures). The primary food category in baseline expenditures among WIC households (Appendix 3) was protein, followed by fruit and vegetables, dairy, snacks, mixed dishes and condiments, grains, dessert, baby food/formula, and non-dairy beverages. These patterns changed only slightly in 2010 .

At baseline, healthy foods accounted for half of the food volume purchased by WIC households (466oz of 940oz, Table 2). Expenditure was, however, dominated by purchases of 
moderation foods (\$82 vs. \$67 for healthy foods); reflecting a higher per-ounce cost of moderation foods such as meats, frozen dinners, desserts. Post-WIC revisions, the volume of healthy food purchased by WIC households went up by $3.9 \%$ and expenditures by $3.1 \%$, increasing the share of healthy foods in the overall food basket. The new WIC subsidies for fruit, vegetables and whole grains were responsible for these improvements (see Appendix 4).

Reductions in moderation foods were small in volume (1.8\%), but larger in expenditure (4.7\%), driven mostly by cheese (reduced WIC allowances) and substitution of refined grains with whole grains. In contrast, comparison subjects reduced purchases of healthy foods in 2010 (by 4\%).

The biggest post-revision improvements in purchases of WIC-participating households were observed for moderation beverages, which declined by $24.7 \%$ in volume and $23.4 \%$ in expenditures (Table 2). This is consistent with the changes in the WIC food packages that introduced restrictions on milk fat content and replaced whole milk (a moderation item) with low-fat/skim milk (a healthy item) for WIC-participating women and children. As low-fat milk purchases replaced whole milk, the share of less healthy beverages declined from $56 \%$ to $49 \%$. This improvement would likely have been even more substantial if reductions in allowances of $100 \%$ juice (a healthy item) did not counteract the growth of healthy beverage purchases. No similar improvements were seen for beverage purchases of comparison households.

Interaction tests to understand if the WIC revisions had differential effects on certain WIC households identified a number of significant trends (Table 3). Households shopping in Massachusetts had a larger increase in healthy and neutral beverage volume and a greater decrease in moderation beverage volume, relative to Connecticut trends. This is likely driven by stricter milk fat restrictions in 2010, not allowing 2\% milk (a moderation item) as in Connecticut, 
but only $1 \% /$ skim milk. There was no effect of shopping in stores in lower socio-economic neighborhoods. WIC households also participating in SNAP did not decrease beverage volume purchased (all health types) at the level of WIC households not participating in SNAP. Larger food budgets among SNAP households may insulate them from the effects of the WIC revisions. Households with infants purchased more neutral food volume following WIC revisions and did not reduce moderation beverage volume to the same levels as households without infants.

\section{DISCUSSION}

There are three key findings of our investigation. First, we show that healthy products comprise the majority of food (but not beverage) purchases among WIC-participating households. Half of the food volume purchased by WIC households was healthy products, while healthy beverages accounted for only $37 \%$ of beverage volume before and $43 \%$ after the WIC revisions. While there is substantial room for improvement, especially for beverages, it appears that WIC favorably affects the nutritional quality of participant purchases. For example, only $30 \%$ of beverage purchases among comparison low-income households were healthy items. This could be an underestimate of WIC's effect due to a history of recent WIC participation in the comparison group. Low-income households that were never exposed to WIC and its nutrition education would probably have a less healthy profile of food purchases and a greater difference with WIC-participating households than the comparison subjects in this study.

Second, we show that the WIC revisions increased the proportion of healthy purchases, particularly for beverages and the overall healthfulness of the product basket purchased by WIC households improved following the WIC revisions. Lack of similar changes for comparison low- 
income households suggests a causal impact of the WIC revisions. The observed improvements appear to align with the changes in the revised WIC packages, including reduced allowances of whole milk, cheese, juice and new allowances for fruit and vegetables and whole grain products. At the same time, participants did not start to purchase more of non-WIC moderation foods, such as sugar-sweetened beverages, sweet baked goods, added sugars, and meats.

Finally, for a large grocery chain in two New England states, we show a post-revision reduction in total food purchases among WIC-participating households, driven entirely by lower beverage purchases and purchases using WIC. Reduced allowances of infant formula, milk and juice in the new WIC packages appear to account for the observed decline in WIC-paid and total purchases. The effect on the grocery chain from reduced WIC purchases is unknown.

Limitations: Data were from two New England states that might differ from other states. Lack of household socio-demographic characteristics is another limitation, yet all households were WIC participants at some point and therefore low-income. The comparison group of former WIC participants could lead to underestimating differences with WIC households as they might have benefited from WIC nutrition education. Finally, the study assessed purchase behaviors at a single grocery chain, which did not include household purchases across all food stores and may not represent overall diets of WIC participants. Our study did not evaluate actual food intake and body weight outcomes. At the same time, there are a number of unique strengths, including detailed purchase data for over 2,100 WIC-participating families in the pre-post revision period, which is linked to nutritional information on foods and beverages purchased and the method of payment used in each transaction. Importantly, our findings of the improved healthfulness of the product basket purchased by WIC participants is consistent with research on the dietary impact 
of the WIC revisions. Multiple studies to date, including national samples of preschool children, showed that dietary quality of WIC participants improved following implementation of the WIC revisions. $^{23-28}$

Conclusion: The revisions of the WIC food packages have improved the healthfulness of the product basket purchased by WIC participants. Healthier food purchases are likely to reflect healthier eating patterns and diet improvements. If sustained, these changes might have significant long-term effects on health care costs and productivity. Given the cost-neutral design of the WIC revisions, the current and future benefits to WIC participants could produce impressive return on investment for taxpayers. The "lessons learned" from the WIC food package revisions may be important to updating other federal food assistance programs. Understanding all of the intended and unintended consequences of the 2007 revisions will be essential in drafting the next round of the WIC food package revisions, expected within next several years. 


\section{REFERENCES}

1. Dubowitz T, Heron M, Bird CE, Lurie N, et al Neighborhood socioeconomic status and fruit and vegetable intake among whites, blacks, and Mexican Americans in the United States. Am J Clin Nutr.2008;87:1883-91.

2. Booth SL, Sallis JF, Ritenbaugh C, Hill JO, et al. Environmental and societal factors affect food choice and physical activity: Rationale, influences, and leverage points. Nutr Rev.2001;59:S21-39.

3. Lovasi GS, Hutson MA, Guerra M, Neckerman KM. Built environments and obesity in disadvantaged populations. Epidemiol Rev 2009;31:7-20.

4. Powell LM, Slater S, Mirtcheva D, Bao Y, Chaloupka FJ. Food store availability and neighborhood characteristics in the United States. Prev Med 2007;44:189-195.

5. Small M, McDermott M. The presence of organizational resources in poor urban neighborhoods: An analysis of average and contextual effects. Social Forces 2006;84:28.

6. Andreyeva T, Blumenthal DM, Schwartz MB, Long MW, Brownell KD. Availability and prices of foods across stores and neighborhoods: The case of New Haven, Connecticut. Health Aff (Millwood).2008;27:1381-8.

7. Block D, Kouba J. A comparison of the availability and affordability of a market basket in two communities in the Chicago area. Public Health Nutr 2006;9:837-45.

8. Vilsack T. USDA accomplishments 2009-2011: United States Department of Agriculture 2011.

9. U.S. Department of Agriculture. WIC program participation and costs. FY2015; http://www.fns.usda.gov/pd/wic-program. Accessed January 5, 2016.

10. Oliveira V, FrazÄo E. The WIC Program: Background, Trends, and Economic Issues, 2015 Edition. EIB-134. U.S. Department of Agriculture, Economic Research Service, January 2015.

11. Institute of Medicine for the National Academies. WIC food packages: Time for a change. Washington, DC, 2005.

12. U.S. Department of Agriculture. Special Supplemental Nutrition Program for Women, Infants and Children (WIC): Revisions in the WIC Food Packages; Final Rule. Federal 
Register Vol. 79(42), March 4, 2014. http://www.fns.usda.gov/sites/default/files/03-0414_WIC-Food-Packages-Final-Rule.pdf. Accessed January 5, 2016.

13. Andreyeva T, Luedicke J, Middleton AE, Long MW, Schwartz MB. Positive influence of the revised Special Supplemental Nutrition Program for Women, Infants, and Children food packages on access to healthy foods. J Acad Nutr Diet 2012;112:850-858.

14. Altarum Institute. Obesity prevention mission project information: Evaluation of women, infants and children (WIC) vendor changes in response to the new WIC food package. 2010; Available from: http://www.altarum.org/research-initiatives-health-systems-healthcare/improving-human-health-systems-mission-projects/childhood-obesity-project-info.

15. Hillier A, McLaughlin J, Cannuscio CC, Chilton M, Krasny S, Karpyn A. The impact of WIC food package changes on access to healthful food in 2 low-income urban neighborhoods. J Nutr Educ Behav 2012;44:210-216.

16. Zenk SN, Odoms-Young A, Powell LM et al. Fruit and vegetable availability and selection: federal food package revisions, 2009. Am J Prev Med 2012;43(4):423-428.

17. Havens EK, Martin KS, Yan J, Dauser-Forrest D, Ferris AM. Federal nutrition program changes and healthy food availability. Am J Prev Med 2012;43(4):419-422.

18. O'Malley K, Luckett BG, Dunaway LF, Bodor JN, Rose D.Use of a new availability index to evaluate the effect of policy changes to the Special Supplemental Nutrition Program for Women, Infants, and Children (WIC) on the food environment in New Orleans. Public Health Nutr 2014;18(1):1-8.

19. Andreyeva T, Luedicke J, Tripp AS, Henderson KE. Effects of reduced juice allowances in food packages for the Women, Infants, and Children program. Pediatrics 2013;131(5):1-9.

20. Andreyeva T, Luedicke J, Henderson KE, Schwartz MB. The positive effects of the revised milk and cheese allowances in the Special Supplemental Nutrition Program for Women, Infants and Children. J Acad Nutr Diet 2014;114(4):622-30.

21. Andreyeva $T$, Luedicke $J$. Incentivizing fruit and vegetable purchases among participants in the Women, Infants, and Children Program. Public Health Nutr 2014; May 9:1-9.

22. Andreyeva T, Luedicke J. Revisions to the WIC food packages and effects on purchases of whole grain products. Am J Prev Med 2013;45(4):422-9.

23. Schultz DJ, Byker Shanks C, Houhtaling B. The impact of the 2009 Special Supplemental Nutrition Program for Women, Infants, and Children food package revisions on participants: a systematic review. J Acad Nutr Diet. 2015;115(11):1832-46.

24. Tester JM, Leung CW, Crawford PB. Revised WIC food packages and children's diet quality. Pediatrics 2016 May;137(50).

25. Spaulding C, Murano P, Girimaji A, Paulhill K, Li Y. Using the National Food and Nutrition Survey (NATFAN) to examine WIC participant food choices and intakes 
before and after changes in the food benefit. Contractor and Cooperator Report No. 82, U.S. Department of Agriculture, Economic Research Service. 2014.

26. Whaley SE, Ritchie L, Spector P, Gomez J. Revised WIC food package improves diets of WIC families. J Nutr Educ Behav 2012;44(3):204-9.

27. Chiasson MA, Findley SE, Sekhobo JP, et al. Changing WIC changes what children eat. Obesity 2013;21:1423-1429.

28. Kong A, Odoms-Young AM, Schiffer LA. The 18-month impact of Special Supplemental Nutrition Program for Women, Infants, and Children food revisions on diets of recipient families. Am J Prev Med 2014;46(6):543-551.

29. Wilde P, Wolf A, Fernandes M, Collins A. Food-package assignments and breastfeeding initiation before and after a change in the Special Supplemental Nutrition Program for Women, Infants, and Children. Am J Clin Nutr 2012; 96(3):560-566.

30. Wilde P, Wolf A, Fernandez M, Collins A. Evaluation of the Birth Month Breastfeeding Changes to the WIC Food Packages, 2011. WIC-12-BF, U.S. Department of Agriculture, Food and Nutrition Service, Special Nutrition Programs.

31. Langellier B, Chaparro P, Wang M, Koleilat M, Whaley S. The new food package and breastfeeding outcomes among women, infants, and children participants in Los Angeles County. Am J Public Health 2014;104:S112-S118.

32. Ogden CL, Carroll MD, Kit BK, Flegal KM. Prevalence of childhood and adult obesity in the United States, 2011-2012. JAMA;2014:311(8):806-14.

33. Ogden CL, Carroll MD, Lawman HG, Fryar CD, Kruszon-Moran D, Kit BK, Flegal KM. Trends in obesity prevalence among children and adolescents in the United States, 19881994 through 2013-2014. JAMA 2016;315(210):2292-9.

34. Sekhobo J, Edmunds L, Whaley S, Koleilat M. Obesity prevalence among low-income, preschool-aged children-New York City and Los Angeles County, 2003-2011. Morbidity and Mortality Weekly Report 2013;62(2).

35. May A, Pan L, Sherry B, et al. Vital Signs: Obesity Among Low-Income, PreschoolAged Children-United States, 2008-2011. 2013; Morbidity and Mortality Weekly Report 62(31).

36. Gladson. Nutrition database. 2011; Available from: http://www.gladson.com/SERVICES/NutritionDatabase/tabid/89/Default.aspx. obtained through TPA with USDA ERS).

37. Information Resources Inc. Nutrition Data 2014. http://www.iriworldwide.com/ (obtained through TPA with USDA ERS).

38. U.S. Department of Agriculture. What We Eat in America. Food Categories 2001-2010. Available at:

http://www.ars.usda.gov/SP2UserFiles/Place/80400530/pdf/0910/food_category_list.pdf

39. Bowman SA, Clemens JC, Friday JE, Thoerig RC, Moshfegh AJ. Food Patterns Equivalents Database 2005-06: Methodology and User Guide. 2014. Food Surveys Research Group, Beltsville Human Nutrition Research Center, Agricultural Research Service, USDA, Beltsville, MD. Available at: http://www.ars.usda.gov/ba/bhnrc/fsrg 
40. U.S. Department of Agriculture. Whole Grain Resource for the National School Lunch and School Breakfast Programs A Guide to Meeting the Whole Grain-Rich Criteria. 2014. Available at: http://www.fns.usda.gov/sites/default/files/WholeGrainResource.pdf

41. Carlson A, Frazão E. Are Healthy Foods Really More Expensive? It depends on How You Measure the Price, EIB-96, U.S. Department of Agriculture, Economic Research Service, May 2012.

42. U.S. Census Bureau. 2006-2010 American Community Survey. Washington, DC: U.S Census Bureau; 2010.

43. Nichols A (2012) Regression for nonnegative skewed dependent variables. BOS10 Stata Conference 2 Stata Users Group 2010. Available at: http://repec.org/bost10/nichols_boston2010.pdf.

44. Hardin JW, Hilbe JM. Generalized Estimating Equations. Boca Raton, FL: Chapman \& Hall/CRC, 2003. 
Table 1: Descriptive Statistics.

Purchases of Low-Income Households, 2009-2010

\begin{tabular}{|c|c|c|c|c|c|c|c|c|}
\hline & \multicolumn{4}{|c|}{ WIC Households } & \multicolumn{4}{|c|}{ Comparison Households } \\
\hline & \multicolumn{2}{|c|}{ Pre-revision } & \multicolumn{2}{|c|}{ Post-revision } & \multicolumn{2}{|c|}{ Pre-revision } & \multicolumn{2}{|c|}{ Post-revision } \\
\hline & Mean & SD & Mean & SD & Mean & SD & Mean & SD \\
\hline Purchased Amounts & \multicolumn{8}{|c|}{ Ounces per Month per Household } \\
\hline Total food \& beverages & 1992 & 1497 & 1869 & 1507 & 1339 & 1359 & 1275 & 1313 \\
\hline Total food & 904 & 791 & 930 & 798 & 726 & 729 & 680 & 691 \\
\hline Total beverages & 1088 & 855 & 939 & 838 & 613 & 742 & 595 & 733 \\
\hline WIC benefit purchases & 549 & 492 & 408 & 395 & & & & \\
\hline Non-WIC funds purchases & 1443 & 1361 & 1460 & 1406 & & & & \\
\hline \multicolumn{3}{|l|}{ Expenditure } & \multicolumn{4}{|c|}{ Dollars $(\$)$ per Month per Household } & & \\
\hline Total food \& beverages & 215 & 172 & 204 & 169 & 153 & 155 & 141 & 144 \\
\hline Total food & 158 & 141 & 160 & 140 & 130 & 133 & 120 & 124 \\
\hline Total beverages & 57 & 54 & 44 & 43 & 23 & 29 & 22 & 26 \\
\hline WIC benefit spending & 48 & 51 & 40 & 43 & & & & \\
\hline Non-WIC spending & 190 & 178 & 185 & 175 & & & & \\
\hline \multicolumn{9}{|c|}{ Household-level controls (monthly) } \\
\hline Number of transactions & 6 & 4 & 5 & 4 & 4 & 4 & 4 & 4 \\
\hline Use of WIC benefits, \% & 86 & 35 & 82 & 39 & 0 & & 0 & \\
\hline Use of SNAP benefits, \% & 45 & 50 & 52 & 50 & 35 & 48 & 34 & 47 \\
\hline Use of non-food EBT, \% & 5 & 22 & 5 & 22 & 3 & 18 & 3 & 16 \\
\hline \multicolumn{9}{|c|}{ Store-Level socio-demographic controls } \\
\hline Household income, \$ & 56,042 & 15,964 & 55,952 & 15,927 & 57,918 & 17,660 & 57,941 & 17,514 \\
\hline College graduates, $\%$ & 16 & 6 & 16 & 6 & 16 & 6 & 16 & 6 \\
\hline Households in poverty $\%$ & 9 & 6 & 9 & 6 & 8 & 6 & 8 & 6 \\
\hline Non-Hispanic white, \% & 83 & 13 & 83 & 13 & 82 & 14 & 82 & 14 \\
\hline Non-Hispanic black, $\%$ & 4 & 5 & 4 & 5 & 4 & 5 & 4 & 5 \\
\hline Unemployed, \% & 8 & 3 & 8 & 3 & 8 & 3 & 8 & 3 \\
\hline Massachusetts, $\%$ & 76 & 42 & 76 & 42 & 67 & 47 & 67 & 47 \\
\hline $\mathrm{N}$ (observations) & 17,844 & & 18,415 & & 6627 & & 6527 & \\
\hline $\mathrm{N}$ (households) & & 2137 & & & & 1303 & & \\
\hline
\end{tabular}


Table 2: Food and Beverage Purchase Changes After WIC Revisions

Purchases of Low-Income Households, 2009-2010

\begin{tabular}{|c|c|c|c|c|c|c|c|c|}
\hline & \multicolumn{4}{|c|}{ WIC Households } & \multicolumn{4}{|c|}{ Comparison Households } \\
\hline & $\operatorname{Exp}(\mathbf{b})$ & $95 \% \mathrm{CI}$ & Pre & Post & $\operatorname{Exp}(\mathbf{b})$ & $95 \% \mathrm{CI}$ & Pre & Post \\
\hline \multicolumn{9}{|c|}{ Ounces Purchased Per Household Per Month } \\
\hline \multicolumn{9}{|c|}{ Total food $\&$ beverages } \\
\hline Healthy items & $1.019^{*}$ & $1.001,1.037$ & 859 & 870 & 0.973 & $0.941,1.006$ & 590 & 577 \\
\hline Neutral items & 0.987 & $0.956,1.019$ & 144 & 143 & 0.975 & $0.924,1.028$ & 137 & 134 \\
\hline $\begin{array}{l}\text { Moderation } \\
\text { items }\end{array}$ & $0.845^{* * *}$ & $0.829,0.861$ & 957 & 836 & $0.952 * *$ & $0.920,0.986$ & 768 & 737 \\
\hline \multicolumn{9}{|l|}{ Food } \\
\hline Healthy items & $1.039 * * *$ & $1.021,1.057$ & 466 & 489 & $0.961^{*}$ & $0.930,0.992$ & 355 & 337 \\
\hline Neutral items & 0.988 & $0.961,1.016$ & 70 & 71 & $0.926^{* * *}$ & $0.889,0.966$ & 57 & 52 \\
\hline $\begin{array}{l}\text { Moderation } \\
\text { items }\end{array}$ & $0.982 *$ & $0.966,0.999$ & 404 & 402 & $0.935 * * *$ & $0.906,0.966$ & 329 & 303 \\
\hline \multicolumn{9}{|l|}{ Beverages } \\
\hline Healthy items & 0.997 & $0.971,1.025$ & 416 & 414 & 0.990 & $0.938,1.046$ & 187 & 182 \\
\hline Neutral items & 0.993 & $0.944,1.045$ & 78 & 78 & 1.020 & $0.940,1.107$ & 66 & 67 \\
\hline $\begin{array}{l}\text { Moderation } \\
\text { items }\end{array}$ & $0.753 * * *$ & $0.733,0.774$ & 617 & 470 & 0.970 & $0.928,1.015$ & 366 & 349 \\
\hline
\end{tabular}

Total food \& beverages

\begin{tabular}{|c|c|c|c|c|c|c|c|c|}
\hline Healthy items & 0.988 & $0.972,1.005$ & 83 & 82 & $0.966^{*}$ & $0.935,0.998$ & 66 & 65 \\
\hline Neutral items & $0.782 * * *$ & $0.742,0.823$ & 32 & 25 & $0.857 * * *$ & $0.816,0.901$ & 18 & 16 \\
\hline $\begin{array}{l}\text { Moderation } \\
\text { items }\end{array}$ & $0.914 * * *$ & $0.899,0.930$ & 99 & 91 & $0.924 * * *$ & $0.895,0.954$ & 88 & 82 \\
\hline \multicolumn{9}{|l|}{ ood } \\
\hline Healthy items & $1.031 * *$ & $1.012,1.049$ & 67 & 70 & $0.965^{*}$ & $0.933,0.999$ & 54 & 51 \\
\hline Neutral items & 0.974 & $0.941,1.007$ & 15 & 14 & $0.862 * * *$ & $0.825,0.901$ & 11 & 10 \\
\hline $\begin{array}{l}\text { Moderation } \\
\text { items }\end{array}$ & $0.953 * * *$ & $0.937,0.970$ & 82 & 80 & $0.917 * * *$ & $0.887,0.947$ & 67 & 60 \\
\hline \multicolumn{9}{|l|}{ Beverages } \\
\hline Healthy items & $0.830 * * *$ & $0.809,0.851$ & 18 & 15 & 0.973 & $0.924,1.025$ & 6 & 6 \\
\hline Neutral items & $0.646^{* * *}$ & $0.594,0.704$ & 18 & 12 & $0.854 * *$ & $0.764,0.954$ & 5 & 4 \\
\hline $\begin{array}{l}\text { Moderation } \\
\text { items }\end{array}$ & $0.766 * * *$ & $0.745,0.787$ & 20 & 16 & 0.975 & $0.929,1.022$ & 12 & 12 \\
\hline
\end{tabular}

Note: Full model results are available from the authors upon request.

Presented are exponentiated coefficients $(\exp (b))$ and $95 \%$ confidence intervals for the binary variable indicating the time periods for the WIC panel: pre (Jan-Sept 2009) and post (Jan-Sept 2010) and for the comparison panel: pre (Apr-Sept 2009) and post (Apr-Sept 2010) from separate GEE regression models for longitudinal data with a logarithmic link function (Poisson family); all models included control variables (SNAP, non-food EBT, number of transactions, socio-demographic store area controls).

Significance levels: $* p<0.05, * * p<0.01, * * * p<0.001$ 
Table 3: Changes in Food and Beverage Volume Purchased After WIC Revisions, Interaction Analysis.

Purchases of Low-Income Households, 2009-2010

\begin{tabular}{lcccccc}
\hline \multirow{2}{*}{ Food } & \multicolumn{6}{c}{ WIC Households, State Interaction Models } \\
\cline { 2 - 7 } & \multicolumn{2}{c}{ Post Period } & \multicolumn{2}{c}{ State } & \multicolumn{2}{c}{ State*Period } \\
\cline { 2 - 7 } Healthy Items & 1.023 & $0.990,1.058$ & $0.862^{* * *}$ & $0.801,0.928$ & 1.021 & $0.983,1.061$ \\
\cline { 2 - 7 } Neutral Items & 0.964 & $0.913,1.018$ & $0.799^{* * *}$ & $0.732,0.872$ & 1.035 & $0.972,1.101$ \\
Moderation Items & $0.937 * * *$ & $0.907,0.968$ & $0.864 * * *$ & $0.806,0.926$ & $1.065^{* *}$ & $1.026,1.105$ \\
Beverages & & & & & & \\
Healthy Items & $0.879^{* * *}$ & $0.835,0.926$ & 1.038 & $0.959,1.123$ & $1.173^{* * *}$ & $1.106,1.245$ \\
Neutral Items & $0.912^{*}$ & $0.838,0.993$ & $0.824^{*}$ & $0.704,0.965$ & $1.121^{*}$ & $1.010,1.243$ \\
Moderation Items & $0.819^{* * *}$ & $0.784,0.856$ & $0.864 * * *$ & $0.805,0.927$ & $0.891^{* * *}$ & $0.844,0.940$ \\
\hline
\end{tabular}

\section{Food}

Healthy Items

\begin{tabular}{cccccc}
\hline \multicolumn{4}{c}{ WIC Households, SNAP Interaction Models } \\
\hline \multicolumn{2}{c}{ Post Period } & \multicolumn{2}{c}{ SNAP } & \multicolumn{2}{c}{ SNAP*Period } \\
\hline $\exp (\mathbf{b})$ & $95 \%$ CI & $\exp (\mathbf{b})$ & $95 \%$ CI & $\exp (\mathbf{b})$ & $95 \%$ CI \\
\hline
\end{tabular}

Neutral Items

$1.050 * * * \quad 1.025,1.074$

$1.305 * * *$

$1.272,1.339$

0.982

$0.954,1.011$

Moderation Items

0.981

$0.944,1.019$

$1.433 * * *$

$1.377,1.491$

1.012

$0.966,1.060$

Beverages

Healthy Items

$0.973 *$

$0.951,0.996$

$1.366^{* * *}$

$1.329,1.403$

1.016

$0.987,1.046$

Neutral Items

Moderation Items

$\begin{array}{ccc}0.960 * & 0.927,0.993 & 1.100 * * * \\ 0.909 * * & 0.846,0.977 & 1.250 * * * \\ 0.708 * * * & 0.683,0.734 & 1.264 * * *\end{array}$

$1.064,1.138$

$1.071 * * *$

$1.028,1.115$

$1.160,1.347$

$1.161 * * *$

$1.065,1.265$

Moderation Items

$0.708 * * * \quad 0.683,0.734$

WIC Households, Infant Models

\begin{tabular}{cccccc}
\hline \multicolumn{2}{c}{ Post Period } & \multicolumn{2}{c}{ Infant } & \multicolumn{2}{c}{ Infant*Period } \\
\hline $\exp (\mathbf{b})$ & $95 \%$ CI & $\exp (\mathrm{b})$ & $95 \%$ CI & $\exp (\mathbf{b})$ & $95 \%$ CI \\
\hline
\end{tabular}

\section{Food}

\begin{tabular}{lcccccc} 
Healthy Items & $1.041^{* * *}$ & $1.022,1.062$ & $1.053^{* * *}$ & $1.030,1.077$ & 1.009 & $0.979,1.041$ \\
Neutral Items & 1.006 & $0.979,1.035$ & $1.478^{* * *}$ & $1.428,1.529$ & $1.063 *$ & $1.015,1.113$ \\
Moderation Items & $0.981^{*}$ & $0.963,0.999$ & $1.052^{* * *}$ & $1.030,1.076$ & 1.023 & $0.992,1.055$ \\
Beverages & & & & & & \\
Healthy Items & 1.015 & $0.986,1.046$ & $1.082 * * *$ & $1.052,1.114$ & 0.963 & $0.925,1.002$ \\
Neutral Items & 1.061 & $0.994,1.134$ & $1.454 * * *$ & $1.363,1.551$ & 0.926 & $0.845,1.014$ \\
Moderation Items & $0.731^{* * *}$ & $0.710,0.752$ & 0.978 & $0.951,1.005$ & $1.101^{* * *}$ & $1.053,1.151$ \\
\hline \hline
\end{tabular}

Note: Full model results are available from the authors upon request. Presented are exponentiated coefficients $(\exp (b))$ and $95 \%$ confidence intervals for the binary variable indicating the time periods for the WIC panel: pre (Jan-Sept 2009) and post (Jan-Sept 2010). Significance levels: * $p<0.05, * * p<0.01, * * * p<0.001$ 


\section{Appendix A: Nutritional Classification of Purchased Foods and Beverages}

Purchases of Low-Income Households, 2009-2010

\begin{tabular}{|c|c|c|c|c|}
\hline \multirow[b]{2}{*}{ Product } & \multicolumn{4}{|c|}{ Number of Unique UPCs } \\
\hline & Healthy & Neutral & Moderation & Total \\
\hline Citrus, Melons, Berries & 249 & 0 & 47 & 327 \\
\hline Other Fruits & 436 & 0 & 181 & 617 \\
\hline 100\% Fruit Juice & 500 & 0 & 0 & 500 \\
\hline Fruit Juice Other than $100 \%$ & 60 & 0 & 5 & 65 \\
\hline Dark Green Vegetables & 216 & 0 & 0 & 216 \\
\hline Red and Orange Veg: Tomatoes & 240 & 0 & 9 & 249 \\
\hline Other Red and Orange & 141 & 0 & 6 & 147 \\
\hline Starchy: Potatoes & 77 & 0 & 0 & 77 \\
\hline Other Starchy Vegetables & 87 & 0 & 13 & 100 \\
\hline Other Vegetables & 750 & 0 & 13 & 763 \\
\hline Beans and Peas (Legumes) & 139 & 0 & 33 & 172 \\
\hline Cooked Grains & 567 & 0 & 45 & 612 \\
\hline Bread, Rolls, Tortillas & 773 & 0 & 277 & 1,050 \\
\hline Cereals & 105 & 0 & 467 & 572 \\
\hline Quick Breads & 47 & 0 & 200 & 247 \\
\hline Flours & 63 & 0 & 0 & 63 \\
\hline Meats & 131 & 0 & 261 & 392 \\
\hline Cured Meat & 209 & 0 & 591 & 800 \\
\hline Poultry & 160 & 0 & 35 & 195 \\
\hline Seafood & 366 & 0 & 87 & 453 \\
\hline Eggs & 43 & 0 & 0 & 43 \\
\hline Soy Products & 45 & 0 & 15 & 60 \\
\hline Nuts and Seeds & 298 & 0 & 45 & 343 \\
\hline Milk & 129 & 0 & 138 & 267 \\
\hline Cheese & 149 & 0 & 727 & 876 \\
\hline Yogurt & 255 & 0 & 176 & 431 \\
\hline Oils and Fats & 0 & 696 & 355 & 1,051 \\
\hline Savory Snacks & 309 & 548 & 236 & 1,093 \\
\hline Crackers & 127 & 259 & 74 & 460 \\
\hline Snack/Meal Bars & 0 & 0 & 236 & 236 \\
\hline Sweet Baked Products & 44 & 7 & 1,979 & 2,030 \\
\hline Candy & 1 & 240 & 1,957 & 2,198 \\
\hline Other Desserts & 54 & 53 & 1,1158 & 1,265 \\
\hline Mixed Dishes & 1,496 & 0 & 2,604 & 4,100 \\
\hline
\end{tabular}




\begin{tabular}{|l|ccc|c|} 
Condiments and Sauces & 162 & 1,365 & 670 & 2,197 \\
Added Sweeteners & 0 & 0 & 456 & 456 \\
Baby Foods & 0 & 404 & 0 & 404 \\
Infant formula & 0 & 95 & 0 & 95 \\
Infant Drinks & 0 & 30 & 0 & 30 \\
Bottled Water & 226 & 0 & 0 & 226 \\
Diet Beverages & 0 & 675 & 0 & 675 \\
Sugary Beverages & 0 & 0 & 1,640 & 1,640 \\
Coffee and Tea & 0 & 912 & 0 & 912 \\
Alcoholic Beverages & 0 & 0 & 531 & 531 \\
\hline TOTAL & $\mathbf{8 , 6 5 4}$ & $\mathbf{5 , 2 8 3}$ & $\mathbf{1 5 , 2 6 7}$ & $\mathbf{2 9 , 2 0 4}$ \\
\hline \hline
\end{tabular}


Appendix B: WIC Household Purchases by Product Sub-Category: Volume

Food Purchases of Low-Income Households, 2009-2010

\begin{tabular}{|c|c|c|c|c|c|c|}
\hline & \multicolumn{3}{|c|}{ Pre WIC Revisions } & \multicolumn{3}{|c|}{ Post WIC Revisions } \\
\hline & Mean, oz & SD, oz & $\%$ Total & Mean, oz & SD, oz & $\%$ Total \\
\hline $\begin{array}{l}\text { Citrus, Melons, } \\
\text { Berries }\end{array}$ & 36.74 & 71.70 & $2 \%$ & 45.80 & 77.17 & $2 \%$ \\
\hline Other Fruits & 69.80 & 102.25 & $4 \%$ & 82.11 & 100.34 & $4 \%$ \\
\hline 100\% Fruit Juice & 189.17 & 176.44 & $9 \%$ & 151.64 & 161.17 & $8 \%$ \\
\hline Other Fruit juice & 4.77 & 23.04 & $0 \%$ & 5.74 & 26.83 & $0 \%$ \\
\hline Dark Green Veggies & 8.76 & 19.39 & $0 \%$ & 9.32 & 19.13 & $0 \%$ \\
\hline $\begin{array}{l}\text { Tomatoes } \\
\text { Other Red and }\end{array}$ & 10.67 & 27.34 & $1 \%$ & 10.47 & 22.27 & $1 \%$ \\
\hline Orange & 9.15 & 22.30 & $0 \%$ & 9.89 & 24.76 & $1 \%$ \\
\hline Potatoes & 24.88 & 49.93 & $1 \%$ & 26.97 & 53.89 & $1 \%$ \\
\hline Other Starchy & 7.50 & 17.70 & $0 \%$ & 8.71 & 19.79 & $0 \%$ \\
\hline Other Vegetables & 38.76 & 59.96 & $2 \%$ & 41.78 & 62.34 & $2 \%$ \\
\hline Beans and Peas & 4.10 & 12.08 & $0 \%$ & 7.56 & 17.68 & $0 \%$ \\
\hline Cooked Grains & 16.74 & 39.16 & $1 \%$ & 18.47 & 41.48 & $1 \%$ \\
\hline Bread, Rolls, & & & & & & \\
\hline Tortillas & 63.38 & 72.91 & $3 \%$ & 71.49 & 71.04 & $4 \%$ \\
\hline Cereals & 32.63 & 35.28 & $2 \%$ & 31.32 & 35.98 & $2 \%$ \\
\hline Quick breads & 9.21 & 18.59 & $0 \%$ & 8.65 & 18.27 & $0 \%$ \\
\hline Flours & 3.11 & 17.70 & $0 \%$ & 3.68 & 19.85 & $0 \%$ \\
\hline Meats & 51.24 & 91.48 & $3 \%$ & 46.25 & 80.33 & $2 \%$ \\
\hline Cured meat & 33.12 & 49.22 & $2 \%$ & 31.39 & 48.63 & $2 \%$ \\
\hline Poultry & 34.77 & 68.41 & $2 \%$ & 37.53 & 73.87 & $2 \%$ \\
\hline Seafood & 7.14 & 20.01 & $0 \%$ & 6.97 & 21.06 & $0 \%$ \\
\hline Eggs & 42.68 & 37.24 & $2 \%$ & 29.81 & 30.36 & $2 \%$ \\
\hline Soy Products & 0.29 & 3.71 & $0 \%$ & 0.43 & 3.81 & $0 \%$ \\
\hline Nuts and Seeds & 11.24 & 16.54 & $1 \%$ & 11.00 & 16.44 & $1 \%$ \\
\hline Milk & 434.82 & 350.06 & $22 \%$ & 319.99 & 280.93 & $17 \%$ \\
\hline Cheese & 33.33 & 33.86 & $2 \%$ & 29.03 & 33.54 & $2 \%$ \\
\hline Yogurt & 18.11 & 32.75 & $1 \%$ & 19.61 & 33.66 & $1 \%$ \\
\hline Oils and Fats & 46.79 & 62.83 & $2 \%$ & 47.24 & 64.45 & $3 \%$ \\
\hline Savory Snacks & 17.90 & 26.39 & $1 \%$ & 18.10 & 26.66 & $1 \%$ \\
\hline Crackers & 7.51 & 14.50 & $0 \%$ & 7.93 & 15.06 & $0 \%$ \\
\hline Snack/Meal Bars & 1.98 & 6.71 & $0 \%$ & 2.06 & 6.89 & $0 \%$ \\
\hline Sweet Baked & & & & & & \\
\hline Products & 42.99 & 58.50 & $2 \%$ & 43.65 & 58.44 & $2 \%$ \\
\hline Candy & 9.48 & 17.64 & $0 \%$ & 10.35 & 19.12 & $1 \%$ \\
\hline Other Desserts & 67.42 & 98.89 & $3 \%$ & 70.31 & 103.66 & $4 \%$ \\
\hline Mixed dishes & 80.43 & 104.42 & $4 \%$ & 81.90 & 108.96 & $4 \%$ \\
\hline Condiments / Sauces & 33.58 & 52.08 & $2 \%$ & 32.33 & 50.89 & $2 \%$ \\
\hline Added Sugars & 18.18 & 37.70 & $1 \%$ & 18.02 & 37.93 & $1 \%$ \\
\hline Baby Foods & 10.56 & 30.78 & $1 \%$ & 9.89 & 31.47 & $1 \%$ \\
\hline
\end{tabular}




\begin{tabular}{|l|cc|c|cc|c|} 
Infant Formula & 9.78 & 35.41 & $0 \%$ & 6.37 & 27.05 & $0 \%$ \\
Infant Beverages & 1.13 & 7.92 & $0 \%$ & 0.93 & 7.32 & $0 \%$ \\
Bottled Water & 84.24 & 204.36 & $4 \%$ & 82.46 & 216.61 & $4 \%$ \\
Diet Beverages & 29.00 & 167.93 & $1 \%$ & 66.74 & 172.35 & $4 \%$ \\
Sweetened & & & & & & \\
Beverages & 291.40 & 455.11 & $15 \%$ & 294.05 & 468.14 & $16 \%$ \\
Coffee and Tea & 4.29 & 11.89 & $0 \%$ & 3.83 & 10.95 & $0 \%$ \\
Alcoholic Beverages & 6.77 & 51.21 & $0 \%$ & 6.98 & 50.35 & $0 \%$ \\
\hline TOTAL & $\mathbf{1 9 9 2 . 5}$ & $\mathbf{1 4 9 6 . 6}$ & $\mathbf{1 0 0 \%}$ & $\mathbf{1 8 6 8 . 8}$ & $\mathbf{1 5 0 7 . 3}$ & $\mathbf{1 0 0} \%$ \\
\hline \hline
\end{tabular}


Appendix C: WIC Household Purchases by Product Sub-Category: Expenditure

Purchases of Low-Income Households, 2009-2010

\begin{tabular}{|c|c|c|c|c|c|c|}
\hline & \multicolumn{3}{|c|}{$\underline{\text { Pre WIC Revisions }}$} & \multicolumn{3}{|c|}{$\underline{\text { Post WIC Revisions }}$} \\
\hline & Mean, \$ & $\mathrm{SD}, \$$ & $\%$ Total & Mean \$ & SD \$ & $\%$ Total \\
\hline $\begin{array}{l}\text { Citrus, Melons, } \\
\text { Berries }\end{array}$ & 4.87 & 8.52 & $2.3 \%$ & 6.53 & 9.78 & $3.2 \%$ \\
\hline Other Fruits & 6.13 & 9.61 & $2.8 \%$ & 7.15 & 9.38 & $3.5 \%$ \\
\hline $100 \%$ Fruit Juice & 11.87 & 10.97 & $5.5 \%$ & 7.46 & 8.28 & $3.7 \%$ \\
\hline Other Fruit juice & 0.27 & 1.41 & $0.1 \%$ & 0.36 & 1.72 & $0.2 \%$ \\
\hline Dark Green Veggies & 1.59 & 3.41 & $0.7 \%$ & 1.80 & 3.64 & $0.9 \%$ \\
\hline Tomatoes & 1.54 & 3.36 & $0.7 \%$ & 1.62 & 3.43 & $0.8 \%$ \\
\hline Other Red and & & & & & & \\
\hline Orange & 0.92 & 2.11 & $0.4 \%$ & 1.06 & 2.30 & $0.5 \%$ \\
\hline Potatoes & 1.46 & 3.04 & $0.7 \%$ & 1.27 & 2.65 & $0.6 \%$ \\
\hline Other Starchy & 0.91 & 2.14 & $0.4 \%$ & 0.97 & 2.05 & $0.5 \%$ \\
\hline Other Vegetables & 4.82 & 7.37 & $2.2 \%$ & 5.34 & 7.69 & $2.6 \%$ \\
\hline Beans and Peas & 0.39 & 1.26 & $0.2 \%$ & 0.69 & 1.66 & $0.3 \%$ \\
\hline Cooked Grains & 1.92 & 3.88 & $0.9 \%$ & 2.06 & 3.92 & $1.0 \%$ \\
\hline Bread, Rolls, & & & & & & \\
\hline Tortillas & 8.89 & 10.44 & $4.1 \%$ & 10.81 & 10.44 & $5.3 \%$ \\
\hline Cereals & 8.72 & 8.94 & $4.0 \%$ & 7.83 & 8.51 & $3.8 \%$ \\
\hline Quick breads & 1.63 & 3.37 & $0.8 \%$ & 1.53 & 3.18 & $0.7 \%$ \\
\hline Flours & 0.15 & 0.97 & $0.1 \%$ & 0.16 & 1.03 & $0.1 \%$ \\
\hline Meats & 10.63 & 18.82 & $4.9 \%$ & 10.37 & 18.16 & $5.1 \%$ \\
\hline Cured meat & 10.15 & 14.36 & $4.7 \%$ & 9.96 & 14.32 & $4.9 \%$ \\
\hline Poultry & 5.39 & 9.89 & $2.5 \%$ & 5.41 & 9.83 & $2.7 \%$ \\
\hline Seafood & 4.04 & 10.88 & $1.9 \%$ & 4.12 & 11.41 & $2.0 \%$ \\
\hline Eggs & 3.49 & 3.34 & $1.6 \%$ & 2.70 & 3.05 & $1.3 \%$ \\
\hline Soy Products & 0.09 & 1.05 & $0.0 \%$ & 0.13 & 1.21 & $0.1 \%$ \\
\hline Nuts and Seeds & 1.97 & 3.27 & $0.9 \%$ & 1.81 & 3.07 & $0.9 \%$ \\
\hline Milk & 15.06 & 12.84 & $7.0 \%$ & 12.37 & 11.11 & $6.1 \%$ \\
\hline Cheese & 10.50 & 10.73 & $4.9 \%$ & 9.02 & 10.37 & $4.4 \%$ \\
\hline Yogurt & 3.02 & 5.92 & $1.4 \%$ & 3.27 & 5.90 & $1.6 \%$ \\
\hline Oils and Fats & 7.06 & 9.38 & $3.3 \%$ & 6.74 & 9.15 & $3.3 \%$ \\
\hline Savory Snacks & 4.82 & 7.24 & $2.2 \%$ & 4.79 & 7.19 & $2.3 \%$ \\
\hline Crackers & 2.11 & 4.16 & $1.0 \%$ & 2.12 & 4.10 & $1.0 \%$ \\
\hline Snack/Meal Bars & 0.76 & 2.59 & $0.4 \%$ & 0.78 & 2.63 & $0.4 \%$ \\
\hline Sweet Baked & & & & & & \\
\hline Products & 9.96 & 14.26 & $4.6 \%$ & 9.94 & 13.98 & $4.9 \%$ \\
\hline Candy & 3.39 & 6.16 & $1.6 \%$ & 3.56 & 6.40 & $1.7 \%$ \\
\hline Other Desserts & 6.41 & 9.54 & $3.0 \%$ & 6.51 & 9.39 & $3.2 \%$ \\
\hline Mixed dishes & 20.47 & 27.31 & $9.5 \%$ & 20.34 & 27.23 & $10.0 \%$ \\
\hline Condiments / Sauces & 4.84 & 7.44 & $2.2 \%$ & 4.67 & 7.31 & $2.3 \%$ \\
\hline Added Sugars & 1.78 & 3.75 & $0.8 \%$ & 1.71 & 3.57 & $0.8 \%$ \\
\hline Baby Foods & 3.36 & 9.21 & $1.6 \%$ & 3.65 & 10.89 & $1.8 \%$ \\
\hline
\end{tabular}




\begin{tabular}{|l|ccc|ccc|} 
Infant Formula & 14.96 & 41.04 & $6.9 \%$ & 8.92 & 30.24 & $4.4 \%$ \\
Infant Beverages & 0.18 & 1.20 & $0.1 \%$ & 0.15 & 1.15 & $0.1 \%$ \\
Bottled Water & 1.59 & 3.91 & $0.7 \%$ & 1.46 & 3.60 & $0.7 \%$ \\
Diet Beverages & 1.88 & 5.42 & $0.9 \%$ & 2.04 & 5.60 & $1.0 \%$ \\
Sweetened & & & & & & \\
Beverages & 8.98 & 13.47 & $4.2 \%$ & 8.70 & 13.08 & $4.3 \%$ \\
Coffee and Tea & 1.72 & 4.60 & $0.8 \%$ & 1.61 & 4.55 & $0.8 \%$ \\
Alcoholic Beverages & 0.65 & 4.45 & $0.3 \%$ & 0.66 & 4.46 & $0.3 \%$ \\
\hline TOTAL & $\mathbf{2 1 5 . 3 4}$ & $\mathbf{1 7 2 . 4 5}$ & $\mathbf{1 0 0 \%}$ & $\mathbf{2 0 4 . 1}$ & $\mathbf{1 6 8 . 5}$ & $\mathbf{1 0 0} \%$ \\
\hline
\end{tabular}




\section{Appendix D: Food and Beverage Purchase Changes After WIC Revisions, Sub-Category}

Analysis

Purchases of Low-Income Households, 2009-2010

\begin{tabular}{|c|c|c|c|c|c|c|c|c|}
\hline & \multicolumn{4}{|c|}{ WIC Households } & \multicolumn{4}{|c|}{ Comparison Households (Q2 - Q3) } \\
\hline & \multicolumn{2}{|c|}{$\begin{array}{c}\text { Pre-Post } \\
\text { Differences in } \\
\text { Purchased Volume }\end{array}$} & \multicolumn{2}{|c|}{$\begin{array}{c}\text { Pre-Post } \\
\text { Differences in } \\
\text { Dollars Spent } \\
\end{array}$} & \multicolumn{2}{|c|}{$\begin{array}{c}\text { Pre-Post } \\
\text { Differences in } \\
\text { Purchased Volume }\end{array}$} & \multicolumn{2}{|c|}{$\begin{array}{c}\text { Pre-Post } \\
\text { Differences in } \\
\text { Dollars Spent }\end{array}$} \\
\hline & $\exp (b)$ & $95 \%$ CI & $\exp (b)$ & $95 \% \mathrm{CI}$ & $\exp (b)$ & $95 \%$ CI & $\exp (b)$ & $95 \% \mathrm{CI}$ \\
\hline $\begin{array}{l}\text { Citrus, Melons, } \\
\text { Berries }\end{array}$ & $1.26 * * *$ & $1.20,1.32$ & $1.33 * * *$ & $1.29,1.37$ & 1.01 & $0.93,1.08$ & $1.11 * *$ & $1.03,1.18$ \\
\hline Other Fruits & $1.20 * * *$ & $1.15,1.23$ & $1.20 * * *$ & $1.16,1.23$ & 1.01 & $0.93,1.09$ & 1.04 & $0.97,1.11$ \\
\hline 100\% Fruit Juice & $0.84 * * *$ & $0.81,0.86$ & $0.65 * * *$ & $0.62,0.66$ & 0.99 & $0.91,1.06$ & 0.97 & $0.89,1.04$ \\
\hline Other Fruit juice & $1.43 * * *$ & $1.22,1.66$ & $1.43 * * *$ & $1.24,1.63$ & 1.29 & $0.95,1.72$ & 1.17 & $0.90,1.50$ \\
\hline Dark Green Veggies & $1.10 * * *$ & $1.04,1.15$ & $1.16^{* * *}$ & $1.10,1.21$ & $0.84 * * *$ & $0.77,0.92$ & 1.00 & $0.92,1.07$ \\
\hline Tomatoes & 0.99 & $0.93,1.05$ & $1.07 * *$ & $1.02,1.12$ & 0.93 & $0.85,1.00$ & 0.95 & $0.88,1.03$ \\
\hline Other Red and & & & & & & & & \\
\hline Orange & $1.14 * * *$ & $1.07,1.20$ & $1.19 * * *$ & $1.13,1.24$ & 0.95 & $0.83,1.07$ & 1.01 & $0.92,1.10$ \\
\hline Potatoes & $1.11 * * *$ & $1.05,1.17$ & $0.89 * * *$ & $0.85,0.92$ & 1.06 & $0.96,1.17$ & $0.89^{* *}$ & $0.82,0.96$ \\
\hline Other Starchy & $1.18^{* * *}$ & $1.12,1.25$ & $1.12 * * *$ & $1.06,1.17$ & 1.04 & $0.93,1.16$ & 0.94 & $0.85,1.02$ \\
\hline Other Vegetables & $1.10 * * *$ & $1.07,1.13$ & $1.13^{* * *}$ & $1.09,1.15$ & 0.95 & $0.89,1.01$ & 1.02 & $0.95,1.08$ \\
\hline Beans and Peas & $1.89 * * *$ & $1.75,2.03$ & $1.75^{* * *}$ & $1.62,1.89$ & 1.03 & $0.88,1.19$ & 1.07 & $0.89,1.28$ \\
\hline Cooked Grains & $1.12 * *$ & $1.03,1.21$ & 1.09 & $0.99,1.19$ & 1.00 & $0.88,1.13$ & $0.92 *$ & $0.85,0.99$ \\
\hline Bread, Rolls, & & & & & & & & \\
\hline Tortillas & $1.16^{* * *}$ & $1.13,1.18$ & $1.24 * * *$ & $1.21,1.26$ & 0.98 & $0.93,1.02$ & 0.97 & $0.92,1.02$ \\
\hline Cereals & $0.97 * *$ & $0.93,0.99$ & $0.92 * * *$ & $0.90,0.94$ & 0.97 & $0.87,1.07$ & 0.99 & $0.92,1.07$ \\
\hline Quick breads & $0.93 *$ & $0.88,0.98$ & 0.97 & $0.92,1.01$ & 0.94 & $0.78,1.12$ & 0.95 & $0.86,1.03$ \\
\hline Flours & $1.26 * * *$ & $1.11,1.42$ & 1.07 & $0.93,1.24$ & 0.96 & $0.78,1.17$ & 0.90 & $0.71,1.11$ \\
\hline Meats & $0.94 * * *$ & $0.91,0.97$ & 1.01 & $0.98,1.04$ & $0.92 *$ & $0.86,0.99$ & 1.03 & $0.96,1.10$ \\
\hline Cured meat & $0.91 * * *$ & $0.86,0.95$ & 1.02 & $0.98,1.04$ & $0.92 *$ & $0.85,0.99$ & 1.00 & $0.94,1.05$ \\
\hline Poultry & $1.10 * * *$ & $1.05,1.15$ & 1.04 & $1.00,1.08$ & 1.06 & $0.97,1.14$ & 0.99 & $0.91,1.07$ \\
\hline Seafood & 0.97 & $0.87,1.07$ & 1.05 & $0.98,1.10$ & $0.83^{*}$ & $0.71,0.96$ & 0.95 & $0.86,1.04$ \\
\hline Eggs & $0.72 * * *$ & $0.70,0.73$ & $0.79 * * *$ & $0.76,0.80$ & 1.03 & $0.97,1.09$ & $1.09 *$ & $1.01,1.16$ \\
\hline Soy Products & $1.55^{* *}$ & $1.12,2.12$ & $1.56^{* *}$ & $1.14,2.11$ & 0.89 & $0.54,1.44$ & 1.47 & $0.99,2.16$ \\
\hline Nuts and Seeds & 1.04 & $0.99,1.08$ & $0.96 *$ & $0.92,0.99$ & 1.05 & $0.90,1.23$ & 0.99 & $0.86,1.12$ \\
\hline Milk & $0.76^{* * *}$ & $0.74,0.77$ & $0.82 * * *$ & $0.80,0.83$ & 0.98 & $0.92,1.02$ & 1.06 & $0.99,1.11$ \\
\hline Cheese & $0.91 * * *$ & $0.86,0.94$ & $0.89 * * *$ & $0.86,0.90$ & 1.03 & $0.92,1.14$ & 1.01 & $0.96,1.06$ \\
\hline Yogurt & $1.14 * * *$ & $1.08,1.18$ & $1.12 * * *$ & $1.06,1.16$ & $1.12 *$ & $1.02,1.22$ & 1.06 & $0.97,1.15$ \\
\hline Oils and Fats & $1.04 * *$ & $1.00,1.06$ & 0.98 & $0.95,1.00$ & 1.04 & $0.98,1.10$ & 0.96 & $0.90,1.01$ \\
\hline Savory Snacks & $1.06 * * *$ & $1.02,1.08$ & 1.03 & $0.99,1.05$ & 1.02 & $0.95,1.08$ & 0.97 & $0.92,1.02$ \\
\hline Crackers & $1.15^{* * *}$ & $1.09,1.20$ & $1.06 * *$ & $1.01,1.09$ & 1.02 & $0.92,1.13$ & 0.94 & $0.86,1.03$ \\
\hline $\begin{array}{l}\text { Snack/Meal Bars } \\
\text { Sweet Baked }\end{array}$ & 1.1 & $0.96,1.25$ & $1.10^{*}$ & $1.01,1.19$ & 1.08 & $0.84,1.38$ & 1.07 & $0.92,1.23$ \\
\hline Products & 1.02 & $0.99,1.05$ & 1.02 & $0.99,1.05$ & 0.97 & $0.91,1.03$ & 0.95 & $0.89,1.00$ \\
\hline
\end{tabular}




\begin{tabular}{|l|cccc|cccc|} 
Candy & $1.11^{* * *}$ & $1.07,1.15$ & $1.06^{* * *}$ & $1.02,1.10$ & 0.96 & $0.86,1.05$ & $0.91 * *$ & $0.85,0.97$ \\
Other Desserts & $1.07 * * *$ & $1.03,1.11$ & $1.04 *$ & $1.00,1.06$ & $1.12^{*}$ & $1.01,1.23$ & 0.99 & $0.93,1.04$ \\
Mixed dishes & $1.06^{* * *}$ & $1.02,1.08$ & 1.01 & $0.98,1.03$ & 1.02 & $0.96,1.07$ & 0.97 & $0.91,1.02$ \\
Condiments / Sauces & $0.96^{*}$ & $0.92,0.99$ & 0.99 & $0.96,1.02$ & $0.93^{*}$ & $0.85,0.99$ & 0.95 & $0.89,1.01$ \\
Added Sugars & 1.01 & $0.96,1.05$ & 0.99 & $0.95,1.03$ & 0.98 & $0.89,1.07$ & 0.97 & $0.88,1.05$ \\
Baby Foods & 0.89 & $0.78,1.00$ & 1.10 & $0.98,1.22$ & $0.32 * * *$ & $0.21,0.49$ & $0.37 * * *$ & $0.27,0.51$ \\
Infant Formula & $0.63 * * *$ & $0.55,0.73$ & $0.62 * * *$ & $0.55,0.69$ & $0.25 * * *$ & $0.12,0.48$ & $0.32 * *$ & $0.14,0.69$ \\
Infant Beverages & $0.77 *$ & $0.61,0.96$ & 0.86 & $0.69,1.06$ & $0.36^{* * *}$ & $0.33,0.37$ & $0.36^{* * *}$ & $0.22,0.57$ \\
Bottled Water & 1.02 & $0.95,1.09$ & $0.93^{*}$ & $0.88,0.98$ & 1.05 & $0.94,1.15$ & 0.97 & $0.88,1.06$ \\
Diet Beverages & $1.08^{*}$ & $1.01,1.15$ & $1.15^{* * *}$ & $1.08,1.22$ & 1.13 & $0.99,1.28$ & 1.06 & $0.96,1.15$ \\
Sweetened Beverages & 1.03 & $0.99,1.06$ & 1.00 & $0.96,1.02$ & 1.03 & $0.96,1.09$ & 1.02 & $0.96,1.06$ \\
Coffee and Tea & 0.93 & $0.86,1.00$ & 0.97 & $0.91,1.02$ & 0.95 & $0.81,1.10$ & 1.01 & $0.91,1.11$ \\
Alcoholic & & & & & & & & \\
Beverages & $1.07 * * *$ & $1.06,1.08$ & 1.08 & $0.92,1.26$ & $0.02^{* * *}$ & $0.01,0.03$ & 0.97 & $0.77,1.21$ \\
\hline \hline
\end{tabular}

Note: ${ }^{\star}$ convergence not achieved

Significance levels: $* p<0.05, * * p<0.01, * * * p<0.001$ 